\title{
STREAMFLOW CHARACTERISTICS OF NORTHEASTERN TASMANIA: II. HYDRAULIC GEOMETRY
}

\author{
by A.D. Knighton
}

(with three tables and six text-figures)

KNIGHTON, A.D., 1987 (30:vi): Streamflow characteristics of northeastern Tasmania: II. Hydraulic geometry. Pap. Proc. R. Soc. Tasm., 121: 125-135. https://doi.org/10.26749/rstpp.121.125 ISSN 0080-4703. Department of Geography, University of Sheffield, Sheffield, SI0 2TN, United Kingdom.

Relationships describing the adjustment of water-surface width, mean depth and mean velocity to increasing discharge are calculated for eleven sections in northeastern Tasmania. The at-a-station graphs of two sections display distinct discontinuities related, however, to different causes - sub-bankfull channelization and the attainment of overbank stage. Despite intra-reach and inter-fluvial variations in hydraulic geometry, two types of response seem to be dominant, characterised by a high rate of change of either depth or velocity. Two sections do not fit into this pattern and, significantly, they tend to plot poorly on downstream graphs.

Bankfull discharge probably lies between Q1.11 and Q2 at most sites, so both flows are used as reference discharges in analyses of downstream adjustment at the regional scale. The relations at Q1.11 and Q2 are quite similar and they are within the envelope defined by results from other areas. However, the data base is small and the scatter is large enough to render the velocity-discharge relation non-significant. The main residual from regression is the station on the South Esk at Perth which is used for discharge measurements at higher flows. Nevertheless, the hydraulic geometry equations enable estimates to be made of channel flow properties at ungauged sites within the northeastern river system.

Key Words: Tasmania, stream flow, hydraulic geometry, bankfull discharge.

\section{INTRODUCTION}

This paper is a companion to Part I (Knighton 1987) which dealt with the variation of several flood discharges at the regional scale. Here, attention focuses on the adjustment within channels to changing discharge at both local and regional scales, using hydraulic geometry as the analytical method.

Adjustments to the internal geometry of the fluvial system involvecomplex interactions a mongst a large number of variables, which cannot be specified by a closed set of equations. Consequently some degree of abstraction or simplification becomes necessary. Certain aspects of the adjustment process can be approached through the technique known as "hydraulic geometry" which was introduced by Leopold \& Maddock (1953) as a means for providing a quantitative description of river behaviour. It rests on two assumptions: that discharge $(\mathrm{Q})$ is the dominant independent variable, and that dependent variables such as width (w), mean depth (d) and mean velocity (v) are related to it by simple power functions:

$$
\begin{aligned}
& \mathrm{w}=\mathrm{a} \mathbf{Q}^{\mathrm{b}} \\
& \mathrm{d}=\mathrm{c} \mathbf{Q}^{\mathrm{f}} \\
& \mathrm{v}=\mathrm{k} \mathbf{Q}^{\mathrm{m}}
\end{aligned}
$$

Given the mass continuity equation, one of the physical relations which a river must satisfy:

$$
Q=w . d . v
$$

it follows that:

$$
\begin{aligned}
& b+f+m=1 \\
& \text { a.c. } k=1
\end{aligned}
$$

where $b, f$ and $m$ are the rates of change of the respective dependent variables, and $\mathrm{a}, \mathrm{c}$ and $\mathrm{k}$ are the corresponding intercept values at unit discharge. The methodology can be applied in two contexts at particular cross-sections ("at-a-station" hydraulic geometry) or along and between rivers ("downstream" hydraulic geometry). In the first, emphasis is placed on temporal changes in flow geometry as discharge fluctuates within the bankfull channel, while the second is concerned with spatial adjustments of flow and channel geometry at a constant frequency of discharge. Both are considered in this paper.

The data have been extracted mostly from the gauging records of the Rivers and Water Supply Commission of Tasmania. Those records were compiled to provide discharge measurements at established gauging stations and not for the 


\section{TABLE 1}

\section{At-a-station relations.}

\begin{tabular}{|c|c|c|c|c|c|c|c|c|}
\hline \multirow[t]{2}{*}{ River } & \multicolumn{6}{|c|}{ Equation constants } & \multirow[t]{2}{*}{ Bed material } & \multirow{2}{*}{$\begin{array}{c}\text { Sample } \\
\text { size }\end{array}$} \\
\hline & $\mathbf{a}$ & b & c & $\mathbf{f}$ & $\mathbf{k}$ & $\mathbf{m}$ & & \\
\hline Cascade (C) & 5.03 & 0.22 & 0.43 & 0.28 & 0.47 & 0.50 & Gravel and coarse sand & 9 \\
\hline $\begin{array}{l}\text { George (G): } \\
\text { (i) Low-flow section } \\
\text { (ii) Cableway section }\end{array}$ & $\begin{array}{l}13.89 \\
11.38\end{array}$ & $\begin{array}{l}0.28 \\
0.20\end{array}$ & $\begin{array}{l}0.20 \\
0.70\end{array}$ & $\begin{array}{l}0.53 \\
0.27\end{array}$ & $\begin{array}{l}0.36 \\
0.12\end{array}$ & $\begin{array}{l}0.19 \\
0.53\end{array}$ & $\begin{array}{l}\text { Mostly sand with } \\
\text { occasional bedrock } \\
\text { exposures }\end{array}$ & $\begin{array}{l}17 \\
13\end{array}$ \\
\hline Great Forester (GF) & 10.29 & 0.22 & 0.29 & 0.50 & 0.33 & 0.28 & Mostly coarse sand & 11 \\
\hline $\begin{array}{l}\text { North Esk }(\mathrm{NE}) \\
\mathrm{Q} \leq 30 \mathrm{~m}^{3} \mathrm{~s}^{-1} \\
\mathrm{Q} \geq 30 \mathrm{~m}^{3} \mathrm{~s}^{-1}\end{array}$ & $\begin{array}{l}8.65 \\
0.90\end{array}$ & $\begin{array}{l}0.15 \\
0.83\end{array}$ & $\begin{array}{l}0.59 \\
1.12\end{array}$ & $\begin{array}{l}0.22 \\
0.03\end{array}$ & $\begin{array}{l}0.20 \\
1.00\end{array}$ & $\begin{array}{l}0.63 \\
0.14\end{array}$ & $\begin{array}{l}\text { Predominantly gravel } \\
\text { but a large range of sizes } \\
\text { from medium sand to small } \\
\text { boulders }\end{array}$ & $\begin{array}{r}25 \\
(23) \\
(4)\end{array}$ \\
\hline Ransom (Ra) & 6.95 & 0.36 & 0.38 & 0.27 & 0.38 & 0.37 & $\begin{array}{l}\text { Gravel and boulders with } \\
\text { coarse sand beneath }\end{array}$ & 12 \\
\hline $\begin{array}{l}\text { Ringarooma (R): } \\
Q \leq 13 \mathrm{~m}^{3} \mathrm{~s}^{-1} \\
Q \geq 13 \mathrm{~m}^{3} \mathrm{~s}^{-1}\end{array}$ & $\begin{array}{r}8.64 \\
18.98\end{array}$ & $\begin{array}{l}0.40 \\
0.09\end{array}$ & $\begin{array}{l}0.24 \\
0.13\end{array}$ & $\begin{array}{l}0.38 \\
0.63\end{array}$ & $\begin{array}{l}0.48 \\
0.41\end{array}$ & $\begin{array}{l}0.22 \\
0.28\end{array}$ & $\begin{array}{l}\text { Gravel with sand and } \\
\text { occasional boulders }\end{array}$ & $\begin{array}{c}33 \\
(19) \\
(15)\end{array}$ \\
\hline $\begin{array}{l}\text { South Esk at Llewellyn }\left(\mathrm{SE}_{\mathrm{L}}\right) \text { : } \\
\text { (i) Low-flow section } \\
\text { (ii) Bonneys Plain } \\
\text { (iii) Cableway section }\end{array}$ & $\begin{array}{l}15.52 \\
18.17 \\
29.24\end{array}$ & $\begin{array}{l}0.12 \\
0.12 \\
0.17\end{array}$ & $\begin{array}{l}0.35 \\
0.23 \\
1.49\end{array}$ & $\begin{array}{l}0.30 \\
0.53 \\
0.21\end{array}$ & $\begin{array}{l}0.18 \\
0.24 \\
0.02\end{array}$ & $\begin{array}{l}0.58 \\
0.35 \\
0.62\end{array}$ & Gravel and boulders & $\begin{array}{l}13 \\
16 \\
17\end{array}$ \\
\hline South Esk at Perth $\left(\mathrm{SE}_{\mathrm{p}}\right)$ & 17.63 & 0.33 & 1.62 & 0.13 & 0.04 & 0.54 & $\begin{array}{l}\text { Mixture of gravel, sand and } \\
\text { silt }\end{array}$ & 11 \\
\hline
\end{tabular}

Symbols: $\mathrm{w}=\mathrm{a} \mathrm{Q}^{\mathrm{b}}, \mathrm{d}=\mathrm{c} \mathrm{Q}^{\mathrm{f}}, \mathrm{v}=\mathrm{k} \mathrm{Q}^{\mathrm{m}}$.

purpose of analysing flow and channel adjustment. Consequently care had to be exercised in building up the data base - sections containing artificial structures were excluded; individual ga ugings which did not adequately specify the water-surface edge were ignored; the remaining records for each station were sampled in a stratified way to ensure a representative range of discharges and, whenever possible, measurements made of width, depth and velocity at the same discharge were checked as to their consistency. At some gauging station sites slightly different sections are used at different discharges, so whether average values were obtained for several sections or results from only one section considered depended on the range of flows covered, with inclusion of the median annual flood $\left(\mathrm{Q}_{2}\right)$ being critical. That discharge forms the basis of the regional-scale analysis.

\section{AT-A-STATION RELATIONS}

As discharge varies at an individual crosssection, changes occur in water-surface width, mean flow depth, velocity and such variables as flow resistance and bed shear stress. To a large extent these changes in flow characteristics are governed by the prevailing dimensions and shape of the channel but they can themselves be altered by the flow, especially during flood discharges. Analysis is usually limited to sub-bankfull flows because of the rapid increase in water-surface width and resultant discontinuity in hydraulic behaviour commonly associated with overtopping of the channel banks and occupation of the adjoining flood-plain. Here, however, only one section was severely affected by such changes.

The stations used in this study are listed in table 1 , together with the relevant coefficient and exponent values. All those values are statistically significant at the $95 \%$ level and for the most part 

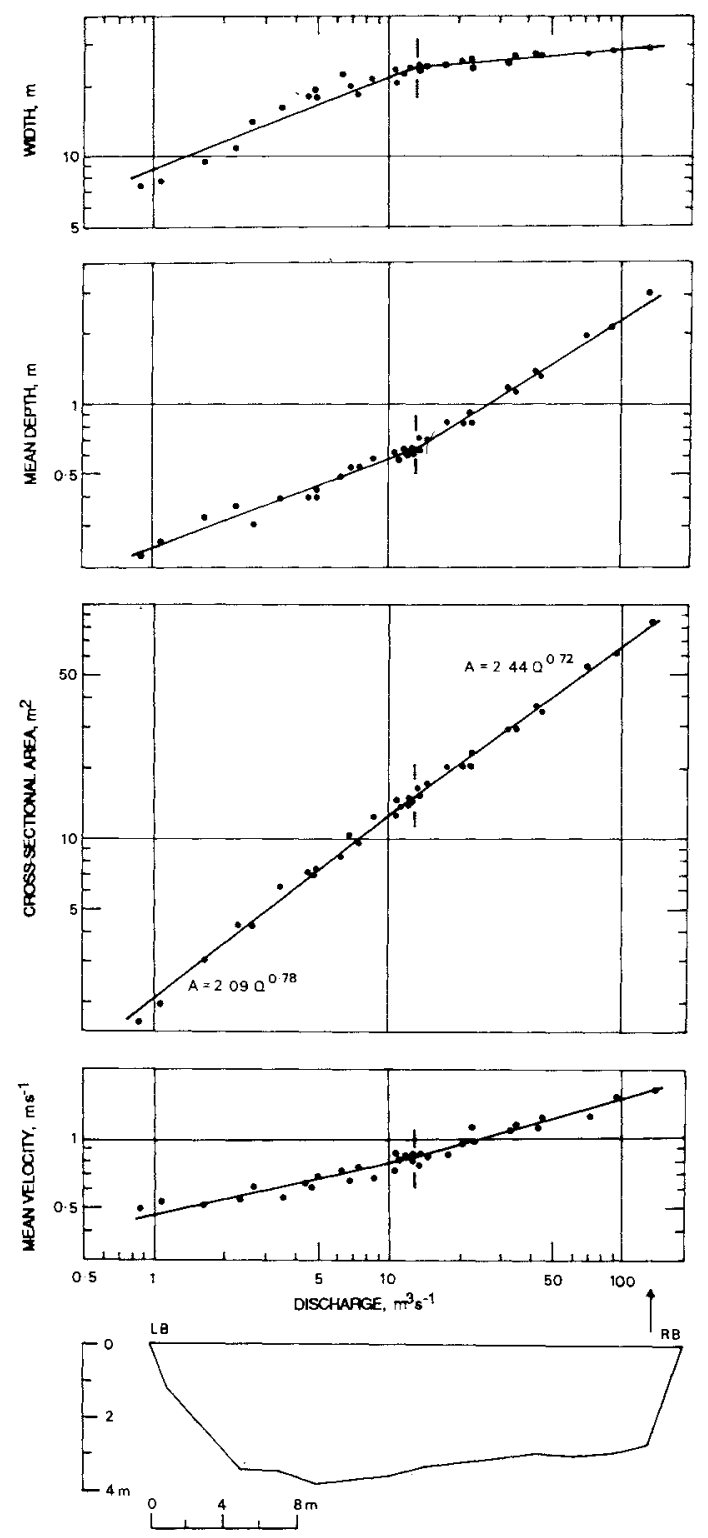

FIG. I At-a-station hydraulic geometry, Moorina, Ringarooma River.

the log-linear plots are well defined with only small a mounts of scatter about regression lines. Scatter is a common feature of many at-a-station graphs and it can come from various sources - measurement error, analytical error, random variation, and
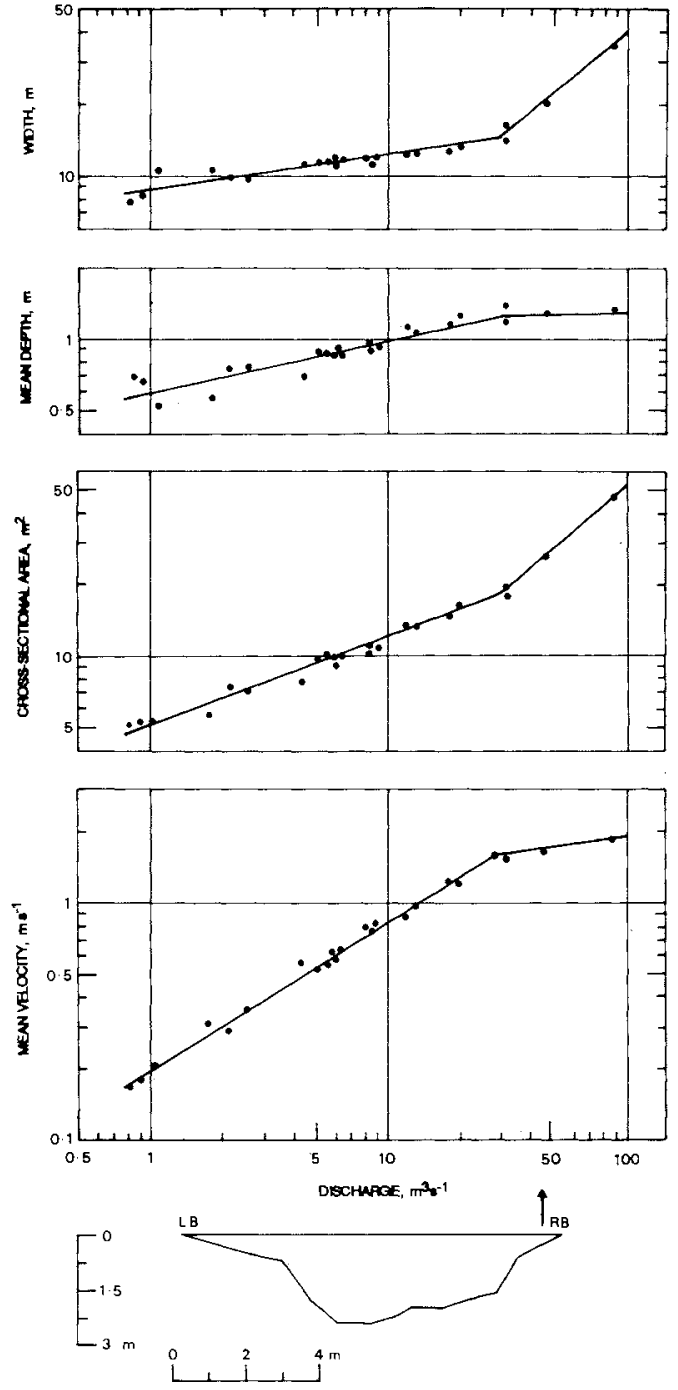

FIG. 2 - At-a-station hydraulic geometry, Ballroom, North Esk River.

systematic change to the channel (Knighton 1977). In the present case where the cross-sections have relatively stable forms the main source was random fluctuation about a modal state, although the data sets at two sections had to be subdivided because of explicit discontinuities (figs 1 and 2) which however were not produced by the same channel condition.

The discontinuity at the Ringarooma section was related to low-flow channelization (the bed of 
the main channel contained a subordinate section), with a distinct change in behaviour at a discharge of about $13 \mathrm{~m}^{3} \mathrm{~s}^{-1}$ (fig. 1). At lower flows the entire bed width of $22 \mathrm{~m}$ was not occupied so that as discharge increased water-surface width increased rapidly at the relatively high rate of 0.40 . In this flow range surface width expansion was preferred to deepening as the means of accommodating larger flow cross-sections, although the distribution of points on the width-and depth-discharge graphs suggests some inconsistencies in the way that was achieved. Above $13 \mathrm{~m}^{3} \mathrm{~s}^{-1}$ the trends are better defined. Following occupation of the entire bed width the flow was contained within relatively steep banks so that width adjustment was limited. In compensation depth became more responsive, increasing at a rate higher than any other in table 1. Throughout this marked transition in width and depth behaviour the cross-sectional area of flow and average velocity were affected surprisingly little, their hydraulic relations showing only slight inflections at the transitional flow. Indeed, although the change in velocity was relatively conservative, it was well defined for such an adjustable variable. This type of discontinuity in hydraulic geometry has been reported elsewhere (Lewis 1966) and Richards (1976) has raised the possibility of more than one break of slope in at-a-station graphs, particularly where bank profiles are highly irregular. Here, however, there was only one break and that occurred at a flow which on average is equalled or exceeded $20 \%$ of the time. Discharges below $13 \mathrm{~m}^{3}$ $\mathrm{s}^{-1}$ are expected to perform only small a mounts of erosional or transportational work at this section.

The discontinuity at the North Esk section occurs at a much higher discharge of about $30 \mathrm{~m}^{3}$ $\mathrm{s}^{-1}$ (fig. 2), a flow with an approximate frequency of $1.5 \%$. Up to that value changes in velocity accomrisudate risost of the increase in dischass, with depth showing a surprisingly limited capacity for adjustment. Also, the depth graph has the largest scatter but, considering the data were a sample of nine years of record, small changes in bed elevation are to be expected. The upper flow range is characterised by a two-fold increase in the rate of change of cross-sectional area caused almost entirely by a pronounced widening of the stream. This, together with the form of the cross-section at $44.5 \mathrm{~m}^{3} \mathrm{~s}^{-1}$ (fig. 2), is evidence that the transitional flow corresponds to bankfull discharge. The much slower rate of change of velocity after the break is attributed to the effects of increased resistance as the flow spills over onto the adjoining flood-plain with its dense vegetation. Unfortunately there are only two data points at discharges much above
$30 \mathrm{~m}^{3} \mathrm{~s}^{-1}$ so that the higher flow response is less certain but extensive patches of fine to coarse sand on the flood-plain suggest frequent overbank stages. If $30 \mathrm{~m}^{3} \mathrm{~s}^{-1}$ is the approximate bankfull discharge, then it is only slightly more frequent than in other humid temperate areas. Bankfull discharge has a modal recurrence interval of about 1.5 years on the annual maximum series according to North American data (Williams 1978a), while a discharge of $30 \mathrm{~m}^{3} \mathrm{~s}^{-1}$ has a recurrence interval of 1.13 years at this section. The duration of overbank flooding in England and Wales is two days a year on average (Nixon 1959), whereas here it is five days a year. Williams (1978a) developed a regression equation for estimating bankfull discharge $\left(Q_{b}\right)$ based on 233 observations,

$$
Q_{b}=4 A_{b}^{1.21} s^{0.28}
$$

where $A_{b}$ is channel capacity at bankfull and $s$ is slope. Applied to North Esk data, it gives a value of $28 \mathrm{~m}^{3} \mathrm{~s}^{-1}$. However, this equation does not apply in eastern Australia (Warner, pers. comm.) and in the Cumberland Basin of New South Wales the return periods of bankfull discharge lie mainly in the range of 4-10 years on the annual series (Pickup \& Warner 1976).

The type of discontinuity represented by the North Esk results is not present to any marked extent in any of the graphs from other sections, even though the data ranges include flows which are larger than the median annual flood $\left(Q_{2}\right)$. The highest flow at the Ringarooma section has an estimated recurrence interval of nearly three years but it is still contained within the confines of the channel (fig. 1). The cross-sectional profiles at the South Esk and George stations contain shelves which might be interpreted as bankfull levels (figs 3 and 4) but neither set of graphs shows much tendency toward discontinuity. In New South Wales rivers, Woodyer (1968) identified up to three such shelves or benches, the highest one representing the present flood-plain level. There, bankfull frequency ranged from 1.24 to 2.69 years.

The Perth station has been chosen to illustrate a high-flow section, its nearest equivalent being the cableway section at Llewellyn. The flow range extends from just above mean annual discharge to almost $Q_{5}$ but unfortunately there is a lack of adequate measurements between 200 and $500 \mathrm{~m}^{3}$ $\mathrm{s}^{-1}$. The cross-section (fig. 3A) has two steps in the right bank profile, an inner smaller one reached at a discharge of approximately $130 \mathrm{~m}^{3} \mathrm{~s}^{-1}$ and an outer more continuous one reached at about $480 \mathrm{~m}^{3} \mathrm{~s}^{-1}$. The latter is the more likely bankfull level but its attainment seems to produce no marked deviation 

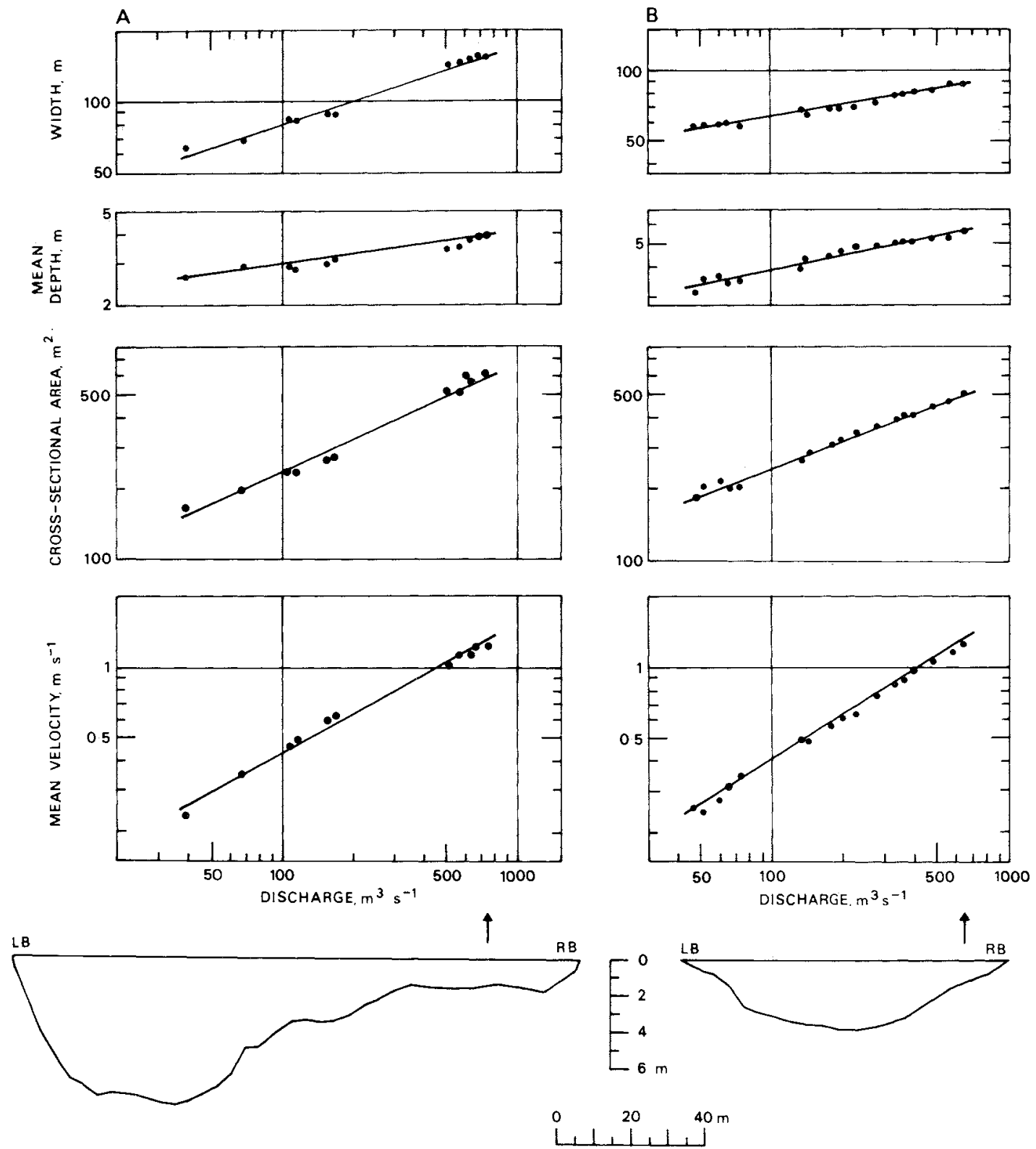

FIG. 3 - At-a-station hydraulic geometry, South Esk River at Perth (A) and Llewellyn (B), cableway sections.

from log-linearity in any of the variables at this very stable section where $Q_{1.11}$ and $Q_{2}$ are respectively 174 and $491 \mathrm{~m}^{3} \mathrm{~s}^{-1}$. However, the main characteristics of the hydraulic geometry are very large depth and very low velocity intercept values (table 1 ). In compensation velocity adjusts relatively quickly to changing discharge so that by about $\mathrm{Q}_{2}$ it has reached $1 \mathrm{~m}^{3} \mathrm{~s}^{-1}$. These features are shared by 

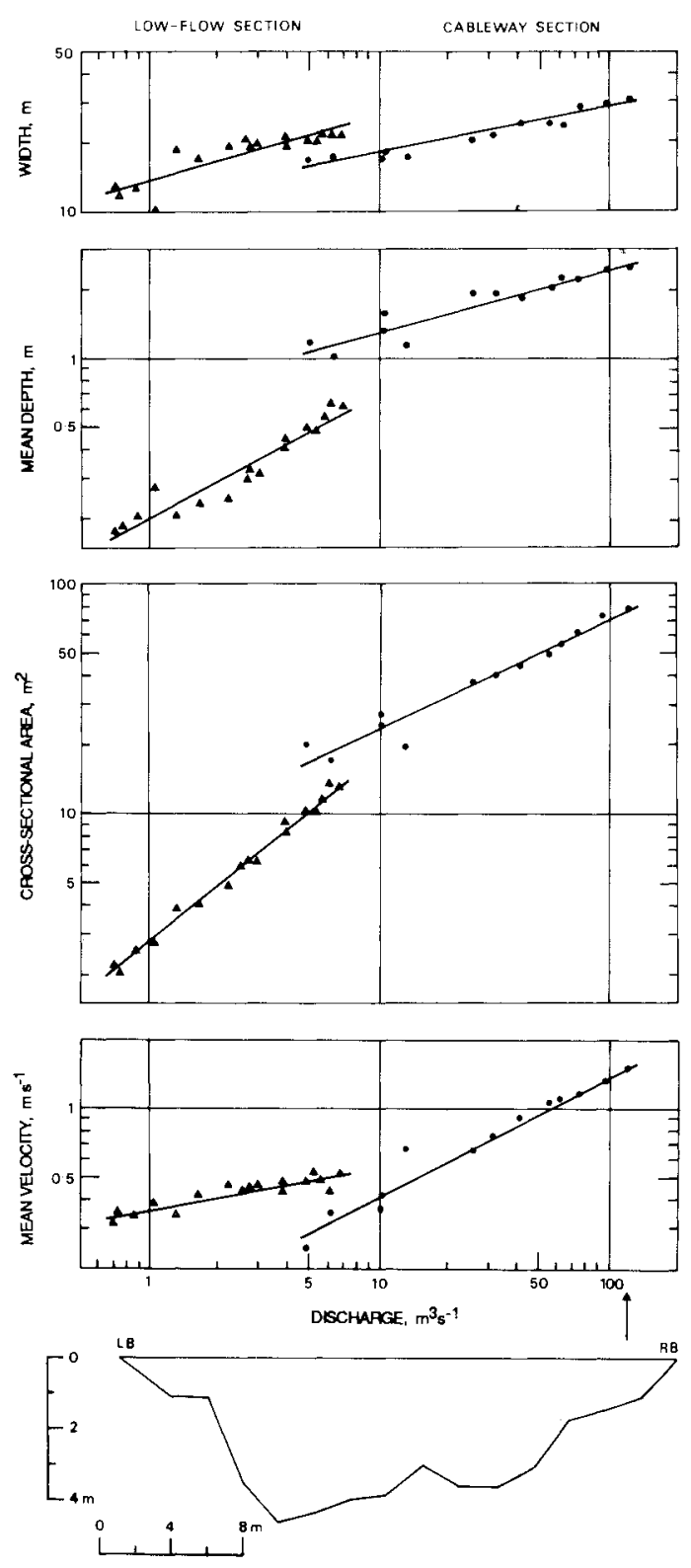

FIG. 4 - At-a-station hydraulic geometry, lowflow and cableway sections at St Helens, George River.

other high-flow sections at Llewellyn (fig. 3B) and, to a lesser extent, on the George (fig. 4) and imply limited capacity to transport coarser bed materials until quite large discharges are reached.

Local scale variations in hydraulic geometry are not uncommon. Differences have been found between straight, curved and divided reaches (Knighton 1975), between pool and riffle sections (Richards 1977), and around a meander bend (Bridge \& Jarvis 1982). Here they are reflected in the variable behaviour of sections used in the measurement of discharge over different ranges. On the George the sections are about $150 \mathrm{~m}$ apart but their hydraulic relations are quite distinct, although there is a hint of continuity in the widthdischarge graph (fig. 4). The main difference lies in the much higher rate of change of velocity, and lower rate of change of depth, at the high-flow section. Its depth and velocity graphs also have quite a lot of scatter at the lower end of the range, suggesting some inconsistency as this sandy-bed section begins to fill. In contrast to the George sections, the low-flow and cableway sections of the South Esk at Llewellyn differ largely in terms of intercept values rather than rates of change (table 1).

The results in table 1 suggest a wice range or responses at both local and regional levels. Rhodes (1977) suggested the method of plotting sets of b-f-m exponents on a triaxial graph, subdividing the diagram into ten channel types delimited by distinct hydraulic criteria (fig. 5A). A plot of 315 data sets revealed the following order in terms of decreasing frequency of occurrence: $2-6-10-8-4-3-$ 5-7-1-9. Five of the sections - NE, $C, G_{C}, S E_{L L}$, $\mathrm{SE}_{\mathrm{LC}}$ - occur in region 2 (fig. 5B), which is the most common and is characterised by $m>f>b$ and $m>f+b$. Such channels are regarded as quite stable and are thought to experience large decreases in resistance with increased discharge. Four of the remaining six sections are also relatively common types - $6\left(\mathrm{SE}_{\mathrm{LBP}}\right), 10\left(\mathrm{R}, \mathrm{G}_{\mathrm{L}}\right), 8(\mathrm{GF})$ - with the Bonneys Plain section in the same region as the most probable state of channel morphology according $\varepsilon_{0}$ the theoretical developments of Langbein $k$ leopold (1964). All have $\mathrm{f}>\mathrm{b}$ and $f>m$, indicating that depth accommodates most of the increase in discharge. That may increase the ability to entrain bed material, because entrainment depends on shear stress which is a direct function of depth, and to drown out resistance elements on the bed. The two remaining sections $\left(\mathrm{SE}_{\mathrm{P}}-\right.$ region 1 , $\mathrm{Ra}$ - region 3) are atypical in having $\mathrm{b}>\mathrm{f}$ so that the width-depth ratio increases with discharge. Nevertheless, despite the high rate of change of width which tends to introduce marginal areas of high resistance to the flow cross-section (Knighton 1975), these sections and particularly $\mathrm{SE}_{\mathrm{p}}$ adjust their velocities quite rapidly.

Two theoretical developments deal explicitly with at-a-station hydraulic geometry; threshold 


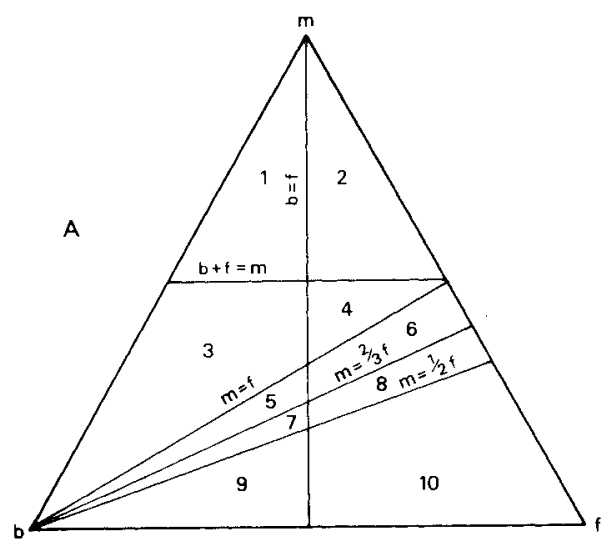

$$
\begin{aligned}
& b>f \quad m>1 / 2 \quad f<m \quad 2 / 3 f<m \quad 1 / 2 f<m \\
& b<t \quad m>\frac{1}{2} \\
& b>f \quad m<\frac{1}{2} \\
& b<t \\
& b>f \quad \bar{f}>\bar{m} \\
& b<f \\
& b>t \\
& b<f \\
& b>f \\
& \mathrm{~b}<\mathrm{f} \\
& \overline{1} / 21>\bar{m}
\end{aligned}
$$
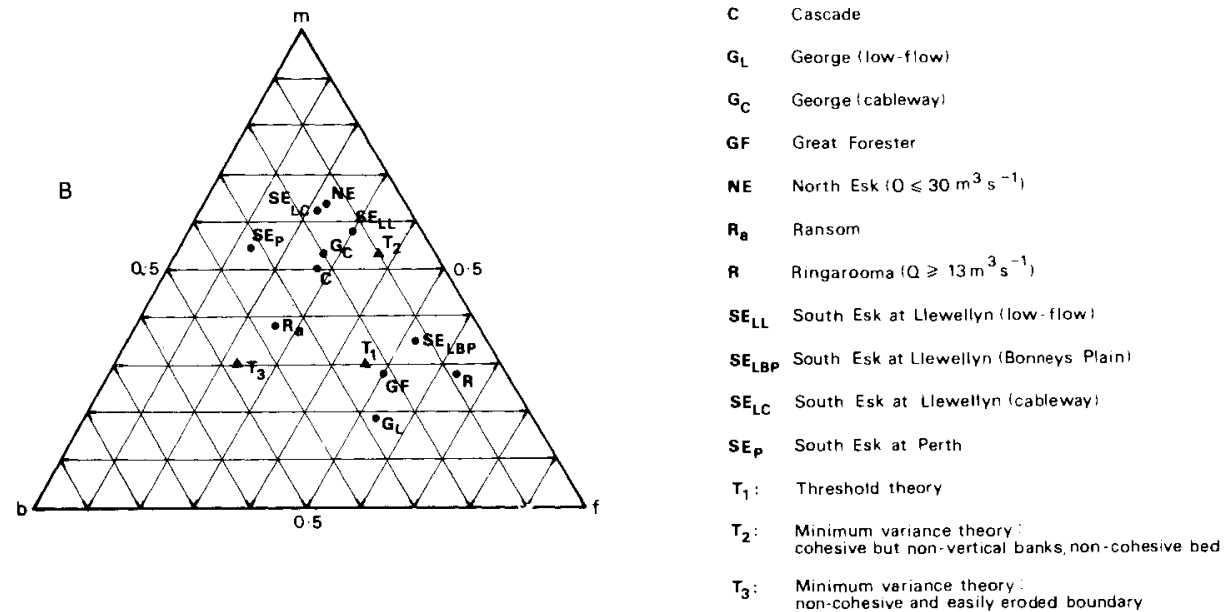

FIG. 5 - Triaxial diagrams showing (A) the ten channel types defined by Rhodes (1977) and (B) a plot of at-a-station exponents. Rates of change of width $(b)$, depth $(f)$ and velocity $(m)$ increase respectively towards bottom left, bottom right and top.

theory which applies to small gravel streams whose boundaries at bankfull discharge are on the threshold of motion (Li et al. 1976), and minimum variance theory which is probabilistic rather than deterministic (Langbein 1964). The theoretical states are plotted on the b-f-m diagram (fig. 5B), with two conditions applied through minimum variance theory (Williams 1978b). It is unlikely that the study sections can be classified as threshold channels, although some may have only limited sediment transport up to bankfull flow, or that they have boundaries which are entirely non-cohesive. Consequently $T_{2}$ is the most applicable state and it lies close to the five sections in region 2 (fig. 5B). However, in overall terms, the most interesting feature of the plot is the tendency for two clusters to form, characterised by rapid adjustment of either velocity $\left(\mathrm{NE}, \mathrm{SE}_{\mathrm{LC}}, \mathrm{SE}_{\mathrm{LL}}, \mathrm{SE}_{\mathrm{P}}, \mathrm{G}_{\mathrm{C}}, \mathrm{C}\right)$ or depth ( $\mathrm{R}$, $\left.\mathrm{G}_{\mathrm{L}}, \mathrm{SE}_{\mathrm{LBP}}, \mathrm{GF}\right)$. Whether there is any significance in $T_{2}$ and $T_{1}$ being approximately associated with these clusters is not known.

At-a-station hydraulic geometry can be strongly influenced by local conditions such as bank material composition. A high silt-clay content in bank material maintains steep bank angles and high resistance to erosion, both of which lead to low width exponents (Knighton 1974). It is perhaps significant that the most consistent set of at-astation relations, that of Wolman (1955), was obtained for a single stream flowing through 
TABLE 2

Downstream relations, northeastern Tasmania.

\begin{tabular}{llcr} 
Discharge & $\begin{array}{l}\text { Hydraulic } \\
\text { relation }\end{array}$ & $\begin{array}{c}\text { Correlation } \\
\text { coefficient }\end{array}$ & $\begin{array}{r}\text { Standard error } \\
\text { of estimate }\end{array}$ \\
\hline $\mathrm{Q}_{2}$ & $\mathrm{w}=3.80 \mathrm{Q}^{0.49}$ & 0.93 & 0.16 \\
$\mathrm{~d}=0.32 \mathrm{Q}^{0.43}$ & 0.98 & 0.08 \\
$\mathrm{~A}=1.22 \mathrm{Q}^{0.92}$ & 0.99 & 0.11 \\
$\mathrm{v}=0.82 \mathrm{Q}^{0.08}$ & 0.55 & 0.12 \\
& (i) with North Esk data & & \\
$\mathrm{Q}_{1.11}$ & $\mathrm{w}=4.0 \mathrm{Q}^{0.50}$ & 0.93 & 0.14 \\
& $\mathrm{~d}=0.33 \mathrm{Q}^{0.45}$ & 0.98 & 0.06 \\
$\mathrm{~A}=1.33 \mathrm{Q}^{0.95}$ & 0.98 & 0.14 \\
$\mathrm{v}=0.75 \mathrm{Q}^{0.05}$ & 0.26 & \\
& (ii) without North Esk data & & 0.13 \\
$\mathrm{w}=4.24 \mathrm{Q}^{0.05}$ & 0.95 & 0.06 \\
$\mathrm{~d}=0.33 \mathrm{Q}^{0.45}$ & 0.99 & 0.10 \\
$\mathrm{~A}=1.40 \mathrm{Q}^{0.95}$ & 0.99 & 0.11 \\
$\mathrm{v}=0.71 \mathrm{Q}^{0.05}$ & 0.36 & \\
\hline
\end{tabular}

uniformly cohesive bank material. There is no such consistency here since the results indicate differences both within the same reach and between rivers. The effects of bank material composition are still to be explored. The remaining question is whether any trends can be discerned in the other context, that of downstream hydraulic adjustment.

\section{DOWNSTREAM RELATIONS}

The selection of a reference discharge is essential for defining downstream trends since it provides the basis for comparing sections at different positions in the drainage network hierarchy. Various discharges have been used, including mean annual flow (Leopold \& Maddock 1953), the 50\%, $15 \%$ and $2 \%$ duration flows (Wolman 1955) and the median annual flood (Bray 1982). Geomorphologists have tended to favour bankfull discharge because of its assumed channel-forming significance but the bankfull state cannot always be defined and is not necessarily associated with a particular flow frequency (Williams 1978a). However, it is probably most appropriate to choose a discharge close to bankfull because flows in that range seem cumulatively to perform most work as regards sediment transport (Wolman \& Miller 1960, Andrews 1980, Webb \& Walling 1982) and are therefore more likely to be responsible for shaping the channel. The at-a-station analysis suggested that the bank- full condition at the study sections lies somewhere between $Q_{1.11}$ and $Q_{2}$, with a tendency toward the latter. Consequently downstream relations are obtained for both flows but with more emphasis on $\mathrm{Q}_{2}$. This is in keeping with Bray's (1982) analysis of Alberta gravel rivers, the most comprehensive so far at the regional scale.

The following procedure was used. Firstly, the flood flows were determined from analyses of annual maximum series except at the Cascade, Great Forester, Ransom and Ringarooma stations where records were not long enough. There the relevant flows were estimated from the regional drainage area relationships (Knight on 1987). Secondly, the width, depth and velocity corresponding to the given discharge were calculated from the at-a-station equations for each section to yield the data required for the regional-scale regression analysis. Several qualifications need to be made. The low-flow sections on the George and South Esk (Llewellyn) were excluded by their very nature. The North Esk results for $\mathrm{Q}_{2}$ were not included because of the marked discontinuity just above $Q_{1.11}$ (fig. 2) and the small number of points in the upper flow range. The hydraulic data for the South Esk at Llewellyn are averages of the Bonneys Plain and cableway sections.

The cross-sectional geometry relationships for the median annual flood are all statistically significant at the 95\% level (table 2), with the depth- 
discharge relation being the most consistent (fig. 6). If width-depth ratio (w/d) is taken as an appropriate parameter of channel shape, the results indicate that channels become more rectangular with increasing discharge but the tendency is only slight. In common with most river systems, crosssectional area (w.d) accommodates most of the increase in discharge with velocity changing very little. Indeed the velocity-discharge relation is not significant but, since velocity is one of the most inherently variable parameters and the rate of change is low, the lack of significance is not unexpected. Bray (1982) found that, although velocity increased with discharge at the regional scale, it might decrease, remain constant or increase along individual rivers.

There is quite a large scatter about regression lines (fig. 6), although it is less than might have been expected considering the small number of data points and the wide range of physiographic conditions which they represent. The most conspicuous residual is the South Esk at Perth which has a wider and shallower section with a lower velocity than the distribution of points would otherwise suggest. The Ransom is also quite a prominent residual and it is perhaps significant that these two stations tend to plot apart from the others on the triaxial diagram of at-a-station conditions (fig. 5B).

The hydraulic relations at $Q_{1.11}$ were calculated without and with the North Esk data (table 2), in order respectively to enable a direct comparison with the $\mathrm{Q}_{2}$ results and to increase the small data base. Despite the difference in discharge magnitude, the average of $Q_{1.11} / Q_{2}$ being 0.42 , the equations for $Q_{1.11}$ and $Q_{2}$ are quite similar, particularly as regards the depth-discharge relation which is again the most consistent. The main difference lies in the width and velocity intercept values. It is also striking that inclusion of the North Esk data produces no significant change in coefficients or exponents, the latter of which remain exactly the same. However, the North Esk was the largest residual, being characterised by a low width and depth and a high velocity, and the results are slightly poorer in statistical terms.

Table 3 shows that the results from northeastern Tasmania overlap those from other areas, with the strongest similarity being in the widthdischarge relation which is commonly regarded as the most regular. Depth tends to adjust more rapidly and velocity more slowly in this area than elsewhere but the differences are relatively small. Indeed there is quite a close affinity between the $\mathrm{Q}_{2}$ relations and those for British gravel-bed rivers. It
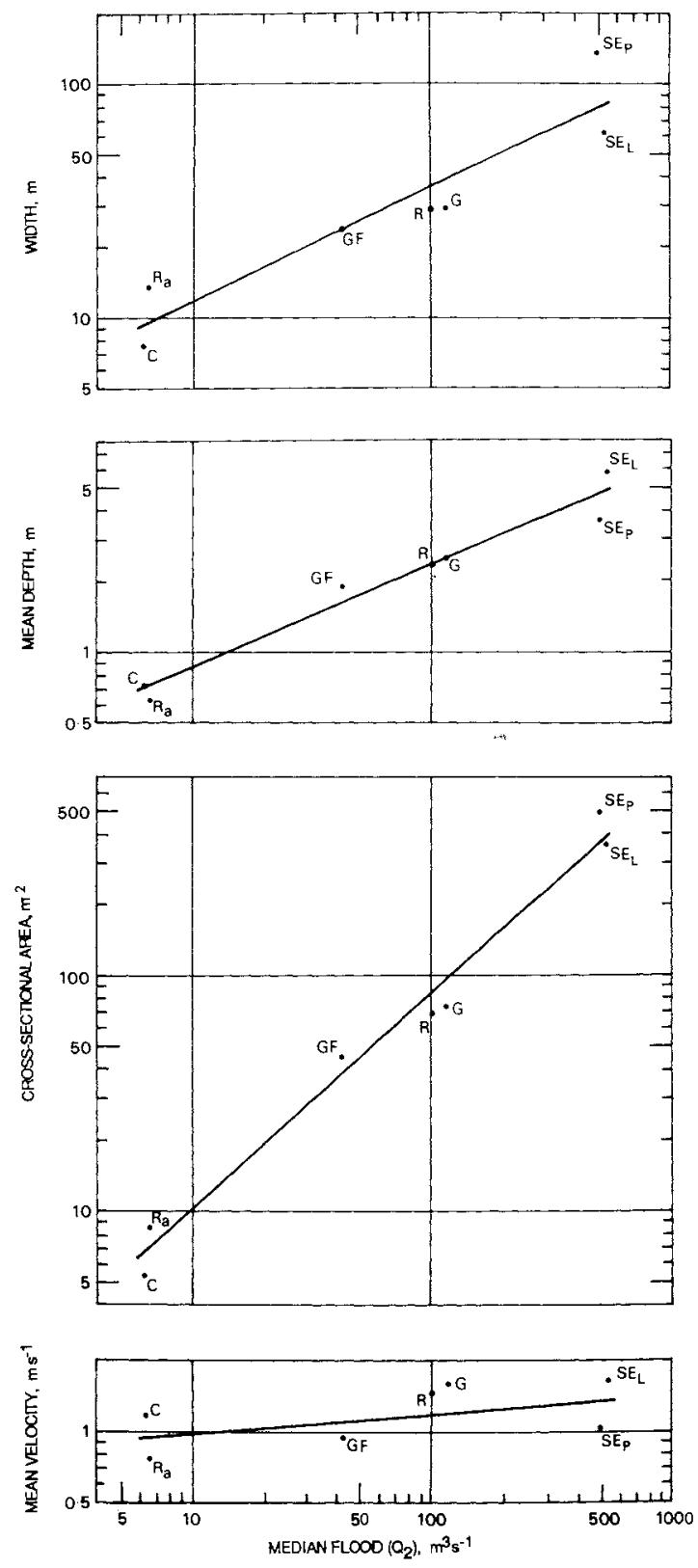

FIG.6 - Downstream hydraulic geometry at the median annual flood.

is interesting also that the Tasmanian results are probably the set closest to Parker's (1979) theoretical predictions which, unlike most, take account of bank stability. Despite the small data base, 
TABLE 3

Downstream hydraulic geometry relations.

\begin{tabular}{|c|c|c|c|c|c|c|c|c|}
\hline Source & Location/applicable & & & $\mathbf{E q}$ & ation & onstar & & \\
\hline & conditions & charge & $\mathbf{a}$ & $\mathbf{b}$ & c & $\mathbf{f}$ & $\mathbf{k}$ & $\mathbf{m}$ \\
\hline This study & Northeastern Tasmania & $\mathrm{Q}_{2}$ & 3.80 & 0.49 & 0.32 & 0.43 & 0.82 & 0.08 \\
\hline & & $Q_{1.11}$ & 4.00 & 0.50 & 0.33 & 0.45 & 0.75 & 0.05 \\
\hline (i) Empirical & & & & & & & & \\
\hline Charlton et al. (1978) & British gravel-bed rivers & $Q_{b}$ & 3.74 & 0.45 & 0.31 & 0.40 & 0.86 & 0.15 \\
\hline Bray (1982) & Alberta gravel-bed rivers & $\mathrm{Q}_{2}$ & 4.79 & 0.53 & 0.26 & 0.33 & 0.80 & 0.14 \\
\hline * Andrews (1984) & Colorado gravel-bed rivers: & & & & & & & \\
\hline & - thick bank vegetation & $Q_{b}$ & 3.91 & 0.48 & 0.49 & 0.37 & 0.52 & 0.15 \\
\hline & - thin bank vegetation & $Q_{b}$ & 4.94 & 0.48 & 0.48 & 0.38 & 0.42 & 0.14 \\
\hline Rundquist (1975) & $\begin{array}{l}\text { Rivers and canals with } \\
\text { gravel and sand beds }\end{array}$ & $Q_{b}$ & 4.39 & 0.52 & 0.38 & 0.32 & 0.60 & 0.16 \\
\hline (ii) Theoretical & & & & & & & & \\
\hline Li et al. (1976) & Threshold theory & $Q_{b}$ & & 0.46 & & 0.46 & & 0.14 \\
\hline * Parker (1979) & $\begin{array}{l}\text { Momentum diffusion, gravel } \\
\text { rivers }\end{array}$ & $\mathrm{Q}_{\mathrm{b}}$ & 4.40 & 0.50 & 0.25 & 0.42 & 0.91 & 0.08 \\
\hline Chang (1980) & $\begin{array}{l}\text { Minimum stream power, } \\
\text { gravel }\end{array}$ & $\mathrm{Q}_{\mathrm{b}}$ & & 0.47 & & 0.42 & & 0.11 \\
\hline
\end{tabular}

Discharge defined as bankfull $\left(Q_{b}\right)$ or the one having a recurrence interval of $2\left(Q_{2}\right)$ or $1.11\left(Q_{1.11}\right)$ years. Symbols: $w=a Q^{b}, d=c Q^{f}, v=k Q^{m}$. * Analysis in terms of dimensionless variables.

therefore, the downstream relations seem to be of the right order of magnitude and may be used to estimate width, depth and velocity at various discharges and locations within the northeast river system.

\section{CONCLUSION}

Hydraulic geometry is essentially two topics in one. At-a-station analysis focuses on the changes in hydraulic parameters as discharge varies through time. Here, it indicates a wide range of responses both within and between study reaches but, when exponent sets are plotted on a triaxial diagram (fig. 5), nine out of the eleven sections prove to be relatively common types. They tend to form two clusters, characterised by a high rate of change of either depth or velocity. The two remaining sections are set apart by their greater inclination toward width adjustment and it may be this distinctive behaviour which makes them the largest residuals in downstream plots (fig. 6)

The at-a-station graphs of two sections contain sharp discontinuities (figs 1 and 2) but they do not reflect the same channel condition. One is related to occupation of the entire bed width at intermediate flows, while the other is associated with the more familiar rapid expansion of width at overbank stage. However, only at that section does the attainment of bankfull produce a significant change in the rates of adjustment of hydraulic variables. Although there is variation from one station to another, bankfull discharge seems to have a recurrence interval between 1.11 and 2 years. $Q_{1.11}$ and $Q_{2}$ were therefore used as the reference discharges in a downstream analysis.

Downstream hydraulic geometry predicts the adjustment of channel dimensions and flow velocity to an imposed discharge. There is little difference between the relations for $Q_{1.11}$ and $Q_{2}$, and they are well within the envelope formed by results from elsewhere. However, the data base is small and no great accuracy can be claimed until more data are available when grouping of like sections may become possible. That would tend to improve the reliability of estimates since welldefined downstream relations require relatively homogeneous controlling conditions. This paper and its companion provide merely an initial basis for estimating streamflow characteristics at ungauged sites. There is a growing awareness of the valuable role that hydraulic geometry can play in a wide variety of river engineering and management activities (Ferguson 1986). 


\section{ACKNOWLEDGEMENTS}

This research was financed by The Royal Society and the University of Sheffield Research Fund. I am also grateful to Dr Les Wood of the Department of Geography, University of Tasmania for providing study facilities; to Mike Williams of the Hydro-Electric Commission for the Bonneys Plain data; and particularly to Douglas Steane and Andrew Livingston of the Rivers and Water Supply Commission for allowing me access to their gauging records.

\section{REFERENCES}

ANDREWS, E.D., 1980: Effective and bankfull discharges of streams in the Yampa River basin, Colorado and Wyoming. J. Hydrol., 46: 311-330.

ANDREWS, E.D., 1984: Bed-material entrainment and hydraulic geometry of gravel-bed rivers in Colorado. Geol. Soc. Amer. Bull., 95: 371-378.

BRAY, D.I., 1982: Regime equations for gravel-bed rivers. In Hey, R.D., Bathurst, J.C. \& Thorne, C.R. (Eds): GRAVEL-BED RIVERS, John Wiley, Chichester: 517-552.

BRIDGE, J.S. \& JARVIS, J., 1982: The dynamics of a river bend: a study in flow and sedimentary process. Sedimentology, 29: 499-541.

CHANG, H.H., 1980: Geometry of gravel streams. $J$. Hydraul. Divn, Amer. Soc. Civ. Engrs, 106: 1443-1456.

CHARLTON, F.G., BROWN, P.M. \& BENSON, R.W. 1978: THE HYDRAULIC GEOMETRY OF SOME GRAVEL RIVERS IN BRITAIN. Hydraulics Research Station, Wallingford, Report IT 180.

FERGUSON, R.I., 1986: Hydraulics and hydraulic geometry. Progress in Physical Geography, 10: $1-31$.

KNIGHTON, A.D., 1974: Variation in width-discharge relation and some implications for hydraulic geometry. Geol. Soc. Amer. Bull., 85: 1069-1076.

KNIGHTON, A.D., 1975: Variations in at-a-station hydraulic geometry. Amer. J. Sci., 275: 186-218.

KNIGHTON, A.D., 1977: Short-term changes in hydraulic geometry. In Gregory, K.J.(Ed.): RIVER CHANNEL CHANGES, John Wiley, Chichester: 101-119.

KNIGHTON, A.D., 1987: Streamflow characterics of northeastern Tasmania: I. Regional flood flows. Pap. Proc. R. Soc. Tasm., 121: 23-33.

LANGBEIN, W.B., 1964: Geometry of river channels. $J$. Hydraul. Divn, Amer. Soc. Civ. Engrs, 90: 301-312.
LANGBEIN, W.B. \& LEOPOLD, L.B., 1964: Quasiequilibrium states in channel morphology. Amer. J. Sci., 262: 782-794.

LEOPOLD, L.B. \& MADDOCK, T., 1953: The hydraulic geometry of stream channels and some physiographic implications. U.S.G.S. Prof. Pap. 252: $57 \mathrm{pp}$.

LEWIS, L.A., 1966: The adjustment of some hydraulic variables at discharges less than $1 \mathrm{cfs}$. Professional Geographer, 18: 230-234.

LI, R.M., SIMONS, D.B. \& STEVENS, M.A., I976: Morphology of cobble streams in small watersheds. J. Hydraul. Divn, Amer. Soc. Civ. Engrs, 102: 1101-1117.

NIXON, M., 1959: A study of the bankfull discharges of rivers in England and Wales. Proc. Instn Civ. Engrs, 12: 157-175.

PARKER, G., 1979: Hydraulic geometry of active gravel rivers. J. Hydraul. Divn, Amer. Soc. Civ. Engrs, 105: 1185-1201.

PICKUP, G. \& WARNER, R.F., 1976: Effects of hydrologic regime on magnitude and frequency of dominant discharge. J. Hydrol., 29: 51-75.

RHODES, D.D., 1977: The b-f-m diagram: graphical representation and interpretation of at-a-station hydraulic geometry. Amer. J. Sci., 277: 73-96.

RICHARDS, K.S., 1976: Complex width-discharge relations in natural river sections. Geol. Soc. Amer, Bull., 87: 199-206.

RICHARDS, K.S., 1977: Channel and flow geometry. Progress in Physical Geography, 1: 65-102.

RUNDQUIST, L.A., 1975: A CLASSIFICATION AND ANALYSIS OF NATURAL RIVERS. Unpubl. $\mathrm{Ph}$.D. thesis, Colorado State University, Fort Collins, Colorado: $377 \mathrm{pp}$.

WEBB, B.W. \& WALLING, D.E., 1982: The magnitude and frequency characteristics of fluvial transport in a Devon drainage basin and some geomorphological implications. Catena, 9: 9-24.

WILLIAMS, G.P., 1978a: Bankfull discharge of rivers. Water Resources Research, 14: 1141-1158.

WILLIAMS, G.P., 1978b: Hydraulic geometry of river cross-sections - theory of minimum variance. U.S.G.S. Prof. Pap. 1029: 47 pp.

WOLMAN, M.G., 1955; The natural channel of Brandywine Creek, Pennsylvania. U.S.G.S. Prof. Pap. 271: 56 pp.

WOLMAN, M.G. \& MILLER, J.P., 1960: Magnitude and frequency of forces in geomorphic processes. J. Geol., 68: 54-74.

WOODYER, K.D., 1968: Bankfull frequency in rivers. J. Hydrol., 6: 114-142.

(accepted 15 September 1986) 